\title{
Skin changes with rickets: looks can be deceptive
}

\author{
Partha Pratim Chakraborty, ${ }^{1}$ Sugata Narayan Biswas, ${ }^{2}$ Himanshu Barman, ${ }^{1}$ \\ Tuhin Subhra Sarkar ${ }^{1}$
}

'Department of Medicine, Midnapore Medical Collge and Hospital, Midnapore, West Bengal, India

${ }^{2}$ Department of Medicine, Midnapore Medical College and Hospital, Midnapore, West Bengal, India

\section{Correspondence to} Dr Partha Pratim Chakraborty, docparthapc@yahoo.co.in

Accepted 8 November 2018

\section{DESCRIPTION}

An $81 / 2$-year-old adopted girl presented to her paediatrician with bowing of her legs and caféau-lait macules and was referred to us with a working diagnosis of rickets in McCune-Albright syndrome (MAS). Clinical examination revealed genu valgum, widening of wrists and two large café-au-lait macules with irregular margins, one involving almost the entire right half of her torso including the right upper limb and the other over left lower back (figures 1 and 2). On a closer look, multiple small dark maculopapular lesions (lentigines) were seen along the entire distribution of the café-au-lait macules with occasional hair

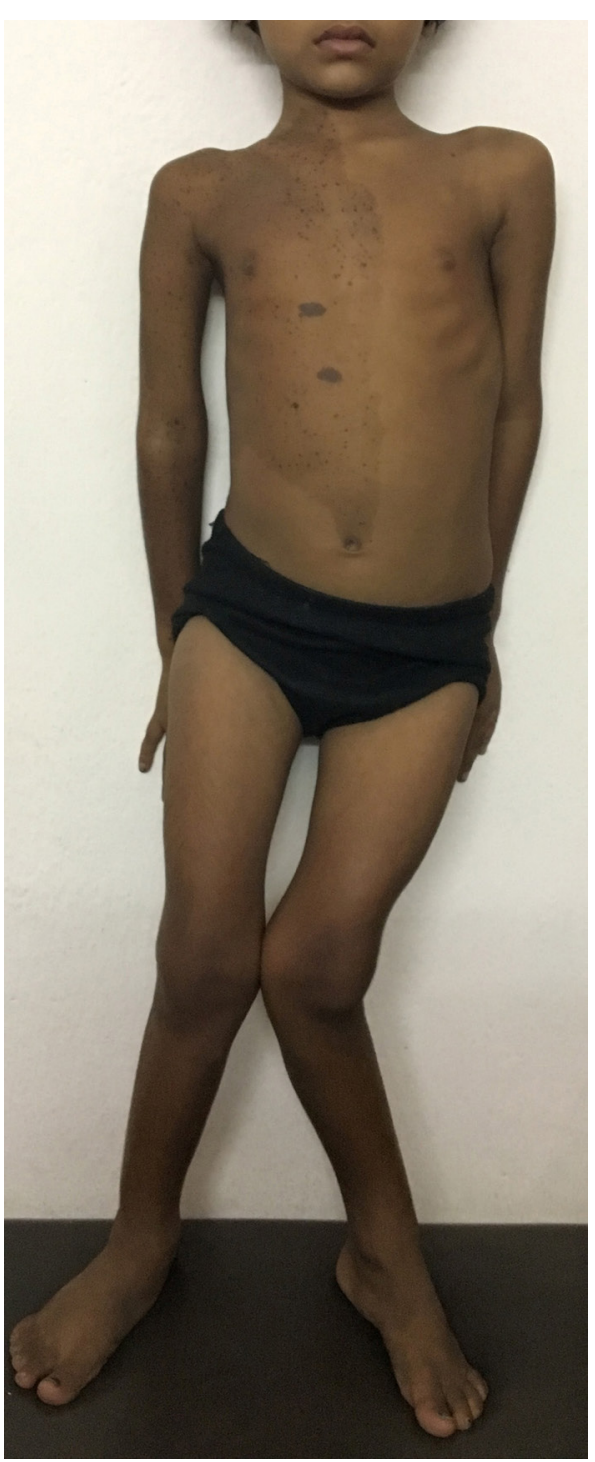

Figure 1 Genu valgum with skin lesion. follicles within favouring the diagnosis of nevus spilus (figure 3). Her standing height was $107.5 \mathrm{~cm}$ (<third centile) and breasts were of Tanner stage 2 without any palpable bony swelling anywhere in the body. Relevant investigations are summarised in table 1.

Typical radiological findings (figure 4), normal albumin corrected calcium, low phosphorus with low tubular maximum reabsorption of phosphate corrected for glomerular filtration rate, grossly elevated alkaline phosphatase and parathormone with low 25-hydroxyvitamin D were suggestive of vitamin $\mathrm{D}$ deficiency rickets. The girl was treated with vitamin $\mathrm{D}$ and calcium with complete radiological recovery. A final diagnosis of vitamin D deficiency rickets coexistent with nevus spilus was made.

Conditions like MAS and the linear nevus sebaceous syndrome (LNSS) are associated with rickets and skin changes. The classical triad of MAS is gonadotropin-independent precocious puberty, polyostotic fibrous dysplasia and caféau-lait pigmentation; however, a number of endocrine and non-endocrine manifestations are also seen at times. At least two features of the typical triad are necessary to make a diagnosis. The caféau-lait macule of MAS typically has an irregular border, known as 'coast of Maine' appearance referring to the jagged morphology of the Maine coastline seen on maps. Moreover, they usually do not cross the midline of the body except in the back; that can be explained by the different patterns of growth of the dermatomes from embryo to maturity. When present, these macules are typically the first manifestation of the disease, usually appearing either at or shortly after birth and as such a potential early clue to underlying MAS. Hypophosphataemia, occasionally encountered in MAS appears to be the result of excessive production of the phosphatonin, fibroblast growth factor (FGF)-23 by the dysplastic bony

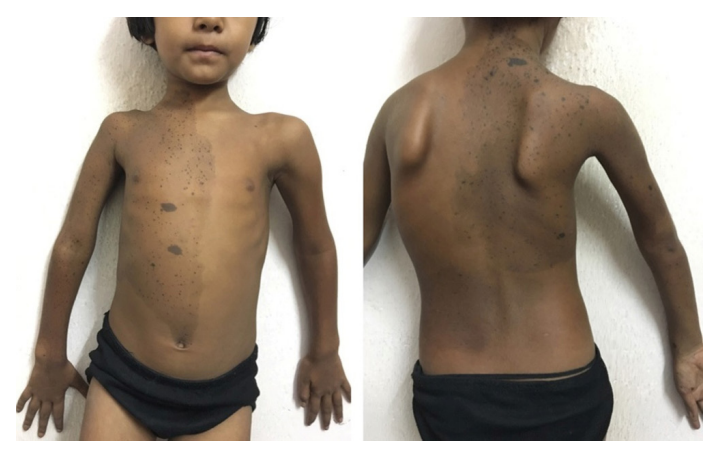

Figure 2 Café-au-lait macules crossing the midline. 


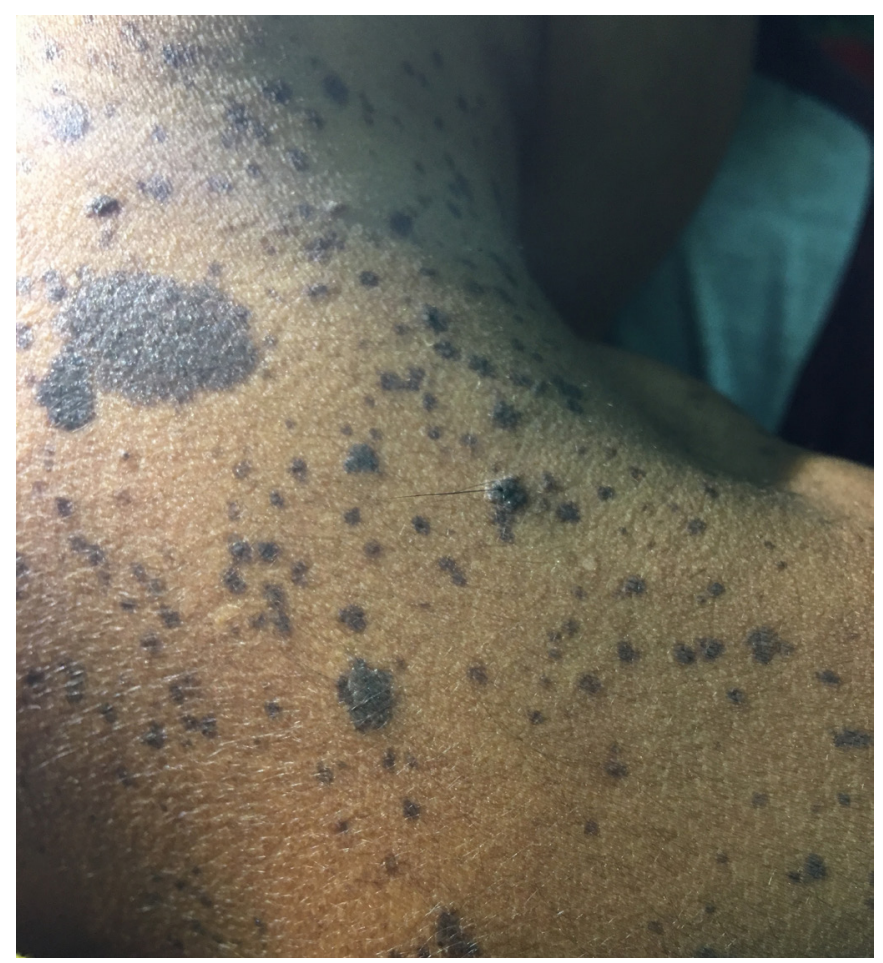

Figure 3 Multiple lentigines with occasional hair within the café-aulait macule present over the right half of torso including neck.

lesions. Rickets/osteomalacia is seen in about 3\% patients of these patients. ${ }^{1}$ LNSS usually appears on the face or on the scalp, and is present since birth or appears in early childhood. This neuroectodermal disorder is characterised by involvement of the skeleton and central nervous systems in addition to ophthalmological, cardiovascular, urological and very rarely endocrine abnormalities like precocious puberty and vitamin D-resistant hypophosphataemic rickets. Elevated FGF-23 has

\begin{tabular}{llc}
\hline Table 1 & Summary of investigations & \\
\hline Parameters & Patient's value & $\begin{array}{l}\text { Age and sex-specific } \\
\text { reference range }\end{array}$ \\
\hline Calcium & $9.2 \mathrm{mg} / \mathrm{dL}$ & $8.5-10.3$ \\
\hline Albumin & $4 \mathrm{~g} / \mathrm{dL}$ & $3.2-4.5$ \\
Phosphorus & $2.4 \mathrm{mg} / \mathrm{dL}$ & $3.2-6.3$ \\
\hline Creatinine & $0.5 \mathrm{mg} / \mathrm{dL}$ & \\
\hline Alkaline phosphatase & $1340 \mathrm{U} / \mathrm{L}$ & $210-935$ \\
\hline Potassium & $3.7 \mathrm{mmol} / \mathrm{L}$ & $3.5-5$ \\
\hline 25-OH-D & $8.8 \mathrm{ng} / \mathrm{mL}$ & $>20$ \\
\hline Parathormone & $243 \mathrm{pg} / \mathrm{mL}$ & $10-65$ \\
\hline Urine creatinine & $45 \mathrm{mg} / \mathrm{dL}$ & \\
Urine phosphorus & $16.9 \mathrm{mg} / \mathrm{dL}$ & \\
\hline TmP/GFR & $0.77 \mathrm{mmol} / \mathrm{L}$ & $1.15-2.44$ \\
\hline Arterial pH & 7.41 & $7.35-7.45$ \\
\hline Bicarbonate & $23 \mathrm{mmol} / \mathrm{L}$ & $22-26$ \\
\hline FGF-23 (c-terminal) & $39 \mathrm{RU} / \mathrm{ml}$ & $<150$ \\
\hline Uterine volume & $1.69 \mathrm{cc}$ & \\
\hline Ovarian volume & Right: $1.14 \mathrm{cc}$ \\
\hline Whole body bone scan & Left: $1.03 \mathrm{cc}$ \\
\hline Unremarkable & \\
\hline
\end{tabular}

25-OH-D, 25-hydroxyvitamin D; FGF-23, fibroblast growth factor 23; TmP/GFR, tubular maximum reabsorption of phosphate corrected for glomerular filtration rate.
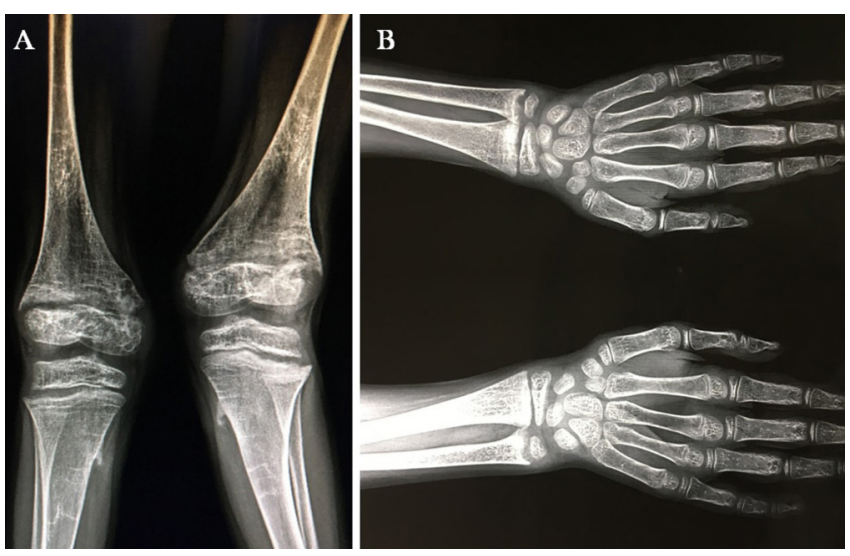

Figure 4 X-rays of knees (A) and wrists (B) showing cupping, fraying and splaying, the typical radiological features of rickets.

consistently been seen in rickets associated with LNSS, but the source of excess FGF-23 still remains debatable. ${ }^{2}$ Nevus spilus (NS) or speckled lentiginous nevus are lesions with background café au lait-like lesions (both macule and papule) speckled with small, 1-3 mm, darker foci and occasional presence of intralesional hairs. These lesions are present since birth and are seen in $1.3 \%-2.3 \%$ of the adult population worldwide and very rarely is associated with hypophosphataemic vitamin D-resistant rickets. ${ }^{3}$

\section{Learning points}

Conditions like McCune-Albright syndrome (MAS), the linear nevus sebaceous syndrome and nevus spilus are associated with cutaneous lesions and vitamin D-resistant hypophosphataemic rickets secondary to elevated circulating fibroblast growth factor 23.

- Nevus spilus, most commonly located over chest and upper limbs consists of a large light tan patch with numerous small superimposed well circumscribed dark brown macules or papules with occasional hairs.

- The café-au-lait macule of MAS classically is uniform with irregular margins and associated with precocity and/or fibrous dysplasia. While these spots do cross the midline, particularly over back, they retain some association to the midline.

Contributors PPC, SNB, HB and were TSS: involved in diagnosis and patient management. PPC: did the literature search and wrote the manuscript.

Funding The authors have not declared a specific grant for this research from any funding agency in the public, commercial or not-for-profit sectors.

Competing interests None declared.

Patient consent Obtained.

Provenance and peer review Not commissioned; externally peer reviewed.

\section{REFERENCES}

1 Styne DM, Grumbach MM. et a/Physiology and disorders of puberty. In: Melmed S, Polonsky KS, Larsen PR, Kronenberg HM, . eds. Williams text book of endocrinology. 13th edn. Philadelphia: Elsevier, 2016:1074-218.

2 Narazaki R, Ihara K, Namba N, et al. Linear nevus sebaceous syndrome with hypophosphatemic rickets with elevated FGF-23. Pediatr Nephrol 2012;27:861-3.

3 Gathings RM, Reddy R, Bhatia AC, et al. Nevus spilus: is the presence of hair associated with an increased risk for melanoma? Cutis 2016;98:171-4. 
Copyright 2018 BMJ Publishing Group. All rights reserved. For permission to reuse any of this content visit https://www.bmj.com/company/products-services/rights-and-licensing/permissions/

BMJ Case Report Fellows may re-use this article for personal use and teaching without any further permission.

Become a Fellow of BMJ Case Reports today and you can:

- Submit as many cases as you like

- Enjoy fast sympathetic peer review and rapid publication of accepted articles

Access all the published articles

- Re-use any of the published material for personal use and teaching without further permission

For information on Institutional Fellowships contact consortiasales@bmjgroup.com

Visit casereports.bmj.com for more articles like this and to become a Fellow 